\title{
The Nutritional Characteristics of Greenhouse Workers Exposed to Intensive Pesticides and Determining the Levels of Xanthine Oxidase, Nitric Oxide and Arylesterase in Their Blood
}

\author{
Yoğun Pestisite Maruz Kalan Sera Işçilerinin Kanlarındaki Ksantin \\ Oksidaz, Nitrik Oksit ve Arilesteraz Seviyelerinin ve Beslenme \\ Alışkanlıklarının Belirlenmesi \\ (10 Serdal Öğüt ${ }^{1}$, (1) Ebru Önem² ${ }^{2}$, (1) Fatih Gültekin ${ }^{3}$, (1) Erdoğan Küçüköner ${ }^{4}$ \\ ${ }^{1}$ Adnan Menderes University Faculty of Health Science, Department of Nutrition and Dietetics, Aydın, Turkey \\ ${ }^{2}$ Süleyman Demirel University Faculty of Pharmacy, Department of Pharmaceutical Microbiology, Isparta, Turkey \\ ${ }^{3}$ Health Sciences University Faculty of Pharmacy, Department of Biochemistry İstanbul, Turkey \\ ${ }^{4}$ Süleyman Demirel University Faculty of Engineering, Department of Food Engineering, Isparta, Turkey
}

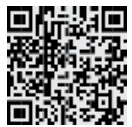

Keywords

Arylesterase, greenhouse workers, nitric oxide, nutritional habits, pesticide, xanthine oxidase

Anahtar Kelimeler

Arilesteraz, sera işçileri, nitrik oksit, beslenme alışkanlıkları, pestisit, ksantin oksidaz

Received/Geliş Tarihi : 03.11.2017

Accepted/Kabul Tarihi : 22.06.2018

doi:10.4274/meandros.galenos.2018.73645

Address for Correspondence/Yazışma Adresi: Serdal Öğüt PhD,

Adnan Menderes University Faculty of

Health Science, Department of Nutrition and

Dietetics, Aydın, Turkey

Phone : +90 2562138755

E-mail : serdalogut@yahoo.com

ORCID ID: orcid.org/0000-0001-8863-7249

(C) Meandros Medical and Dental Journal, Published by Galenos Publishing House.

This is article distributed under the terms of the

Creative Commons Attribution NonCommercial 4.0

International Licence (CC BY-NC 4.0).

\begin{abstract}
Objective: Agricultural spraying in greenhouses may cause workers be exposed to the adverse effects of pesticides more than outdoor land workers. High dose application and spraying of pesticides without prevention may increase risks of harmful effect remarkably. In this study, influence of greenhouse workers from pesticides was investigated.

Materials and Methods: For this study 74 people were chosen, including 44 workers who have been exposed to pesticides and 30 people who have never been directly exposed pesticides. To compare continuous variables, the Student's t-test was used where appropriate.

Results: According to nutritional habits $52.5 \%$ of greenhouse workers consumed their production of tomatoes and also other fruits and vegetables without washing. In addition, 59\% of greenhouse workers have consumed water and 54.5\% of them have consumed some food while spraying pesticides. The statistics showed that levels of xanthine oxidase (XO) and nitric oxide (NO) in pesticides-exposed workers were significantly higher in comparison to non-exposed group and the level of ARE was significantly lower in pesticides-exposed workers when compared with nonexposed group, respectively $(\mathrm{p}<0.05)$.

Conclusion: The results of study revealed that levels of XO and NO in study group were significantly $(p>0.05)$ higher than control group and the level of arylesterase was significantly $(p<0.05)$ lower than control group, respectively.
\end{abstract}

Öz

Amaç: Sera iş̧̧ileri açık alan tarım işçilerine kıyasla pestisitlerin zararlı etkilerine daha fazla maruz kalabilirler. Gerekli koruma önlemleri alınmadan yapılan pestisit uygulamaları, uygulayıcılarda dikkate değer şekilde sağlık problemlerini artırmaktadır. Bu çalışmada sera iş̧̧ilerinin pestisitlerden etkilenme durumu araştırılmıştır.

Gereç ve Yöntemler: Bu araştırmada, en az 3 senedir seralarda zirai ilaçlama yapan işçilerin kanlarında ksantin oksidaz (XO), nitrik oksit (NO) ve arilesteraz enzim 
seviyeleri araştırılmıştır. Buna ek bu işçilerin beslenme alışkanlıkları da değerlendirilmiştir. Bu amaçla 74 kişi çalışmaya dahil edilmiştir. Bu kişilerden 44'ü seralarda çalışan tarım işçilerinden oluşturulan araştırma grubu, 30'u ise hayatlarının hiçbir döneminde doğrudan pestisite maruz kalmamış kişilerden oluşturulan kontrol grubudur.

Bulgular: Yapılan analizler sonucu tarım işçilerinden oluşan araştırma grubunun $\mathrm{XO}$, NO değerlerinin kontrol grubuna göre anlamlı artığı, arilesteraz enzim seviyelerinin ise anlamlı azaldığı belirlenmiştir $(p<0,05)$. Tarım işçilerinin beslenme alışkanlıkları değerlendirildiğinde ise; işçilerin \%52,5'inin tükettikleri meyve ve sebzeleri yıkamadan tükettikleri belirlenmiştir. Buna ek olarak işçilerin pestisit uygulaması yaparken \%59'unun su tükettiği, \%54,5'inin ise bazı besinler tükettiği belirlenmiştir.

Sonuç: Çalışma sonuçları değerlendirildiğinde, deney grubunun XO ve NO seviyeleri kontrol grubundan anlamlı $(p<0,05)$ yüksek, arilesteraz sevileri ise anlamlı $(p<0,05)$ düşük bulunmuştur.

\section{Introduction}

Organophosphate pesticides (OPs), synthetic pyrethroid and carbamates are the most commonly used insecticides worldwide for the pest control of crops. With the green revolution and industrialization, they have become household items of agriculturists $(1,2)$. Pesticides are mainly used in the agricultural sector in Turkey, too. While OPs are commonly used in Turkey, the use of organochlorines is not allowed because of their high toxicity, compose of endosulfan and dicofol. Considering the research, consumption of pesticide has increased 45\% between 1979 and 2012 in this country. And forty percent of annual pesticide used takes place in the Mediterranean and Aegean regions $(3,4)$.

Exposed to pesticides cause harmful effect on agriculture and agricultural spraying workers. The most affected parameters in oxidant and antioxidant systems within agriculture and greenhouse workers are the levels of xanthine oxidase (XO), nitric oxide (NO), catalase and superoxide dismutase and arylesterase (ARE). ARE, is related to increased susceptibility to low density lipoprotein oxidation and development of atherosclerosis (5-12).

Nutritional habits and diet style have great importance in every age and every occupational group. Intensive nutrition becomes even more important in workers exposed to pesticides (9).

In this study the workers who are so heavily exposed to pesticides while spraying in greenhouses and the XO, ARE and NO levels in their blood were investigated, and nutritional characteristics were determined.

\section{Materials and Methods}

This experimental study was conducted between 2010 and 2011 in Isparta, Turkey. Fourty-four greenhouse workers who have worked at greenhouse (applying insecticides on tomato and carnation agriculturally) at least 3 years were taken as models for this research. The study was approved by the Research Ethics Committee of Süleyman Demirel University (20.02.2008 date, 01-17 number). All participants gave their verbal and written consents. In this study 74 individuals (44 subjects, 30 control group) were selected. The results of a power analysis, with power $84.9 \%$ and a significance level (alpha) of 0.050 suggested that a selection of 74 patients was sufficient for the sample. The control group consisted of persons who were not directly exposed to pesticide. Demographic characteristics (gender, age, BMI etc.) were calculated with descriptive statistics (Student's t-test). The characteristics of the control group and the study group were chosen to be similar $(p>0.05)$ (Table 1).

Detection of XO, NO, ARE Level: The blood samples of each group were collected and the levels of $\mathrm{XO}$, $\mathrm{NO}$ and ARE in blood samples were analyzed. Blood samples of the study group were obtained 30 minutes after the pesticide application into the ethylene diamine tetraacetic acid tubes. Blood samples were transfered to the laboratory in appropriate cold boxes.

Blood samples centrifuged (Nüve brand NF-400 model centrifuge) at $3000 \mathrm{~g}$ for 15 minutes. First of all erythrocytes were filtered by taking into the eppendorf tubes after the end of centrifuge. Than erythrocytes were washed by serum physiological for 3 times and stored at $-80{ }^{\circ} \mathrm{C}$ in deepfreeze until operation day. Analogously, plasma samples which were taken into eppendorf tubes stored at $-80{ }^{\circ} \mathrm{C}$ in deep freeze until operation day. The blood samples of control group who have never been exposed to pesticides were prepared analogously and stored. Then, all blood samples were diluted 10 times with cold deionizes water. All spectrophotometric analyses were carried out by Perkin Elmer marked UV/Vis model lamb 20 spectrophotometer. 


\begin{tabular}{|c|c|c|c|c|}
\hline & \multicolumn{2}{|l|}{$\begin{array}{l}\text { Study } \\
n=44\end{array}$} & \multicolumn{2}{|l|}{$\begin{array}{l}\text { Control } \\
n=30\end{array}$} \\
\hline Age & \multicolumn{2}{|l|}{$39.4 \pm 8.7$} & \multicolumn{2}{|l|}{$38.4 \pm 7.5$} \\
\hline $\mathrm{BMI}\left(\mathrm{kg} / \mathrm{m}^{2}\right)$ & \multicolumn{2}{|l|}{$24.3 \pm 3.2$} & \multicolumn{2}{|l|}{$25.6 \pm 3.6$} \\
\hline Gender & Male & Female & Male & Female \\
\hline$n(\%)$ & $36(81.8)$ & $8(18.2)$ & $36(81.8)$ & $8(18.2)$ \\
\hline Smoking & Yes & No & Yes & No \\
\hline (Ten or more smokers a day) & 24 & 20 & 16 & 14 \\
\hline Alcohol & Yes & No & Yes & No \\
\hline (Consuming alcohol at least once a week) & 8 & 36 & 7 & 23 \\
\hline
\end{tabular}

Table 2. Nutrition questionnaire in green house workers

\begin{tabular}{|c|c|c|c|}
\hline Questions & Options & $\mathbf{n}$ & $\%$ \\
\hline \multirow[t]{4}{*}{ How many times do you eat meal for a day? } & 1 meal & 0 & 0.0 \\
\hline & 2 meals & 6 & 13.8 \\
\hline & 3 meals & 30 & 68.1 \\
\hline & $>3$ meals & 8 & 18.1 \\
\hline \multirow[t]{2}{*}{ Do you skip breakfast? } & Yes & 12 & 27.2 \\
\hline & No & 32 & 72.8 \\
\hline \multirow[t]{2}{*}{ Do you skip lunch? } & Yes & 8 & 18.1 \\
\hline & No & 36 & 71.9 \\
\hline \multirow[t]{2}{*}{ Do you skip dinner? } & Yes & 2 & 4.5 \\
\hline & No & 42 & 95.5 \\
\hline \multirow[t]{2}{*}{ Do you eat snacks? } & Yes & 4 & 9 \\
\hline & No & 40 & 91 \\
\hline \multirow{2}{*}{$\begin{array}{l}\text { Do you eat fruits without peeling or washing during application of pesticides to apples/ } \\
\text { cherries or after application of pesticides? }\end{array}$} & Yes & 22 & 50 \\
\hline & No & 22 & 50 \\
\hline \multirow[t]{2}{*}{ Do you eat tomatoes before application of pesticides without washing? } & Yes & 23 & 52.2 \\
\hline & No & 21 & 47.8 \\
\hline \multirow[t]{2}{*}{ Do you eat other food/fruits during application of pesticides? } & Yes & 24 & 54.5 \\
\hline & No & 20 & 45.5 \\
\hline \multirow[t]{2}{*}{ Do you drink water during application of pesticides? } & Yes & 26 & 59 \\
\hline & No & 18 & 41 \\
\hline \multirow[t]{4}{*}{ How many times do you eat meat per week? } & No & 4 & 9 \\
\hline & 1-3 times & 31 & 70.4 \\
\hline & 4-6 times & 9 & 20.6 \\
\hline & 6 times & 0 & 0.0 \\
\hline \multirow[t]{4}{*}{ How many times do you eat vegetables per week? } & No & 0 & 0.0 \\
\hline & 1-3 times & 32 & 72.7 \\
\hline & $4-6$ times & 8 & 18.1 \\
\hline & $>6$ times & 4 & 9.2 \\
\hline
\end{tabular}




\section{Table 2. contiuned}

\begin{tabular}{|c|c|c|c|}
\hline \multirow[t]{4}{*}{ How many times do you eat fruits per week? } & No & 0 & 0.0 \\
\hline & 1-3 times & 7 & 15.9 \\
\hline & 4-6 times & 15 & 34.1 \\
\hline & $>6$ times & 22 & 50 \\
\hline \multirow[t]{4}{*}{ How many times do you drink milk per week? } & No & 18 & 40.9 \\
\hline & 1-3 times & 18 & 40.9 \\
\hline & 4-6 times & 8 & 18.2 \\
\hline & $>6$ times & 0 & 0.0 \\
\hline \multirow[t]{4}{*}{ How many times do you eat milk products such as yogurt, cheese, and butter vs per week? } & No & 0 & 0.0 \\
\hline & 1-3 times & 6 & 13.7 \\
\hline & 4-6 times & 20 & 45.4 \\
\hline & $>6$ times & 18 & 40.9 \\
\hline \multirow[t]{4}{*}{ How do you eat fruits? (\%) } & After wash & 15 & 34.1 \\
\hline & After peel & 7 & 15.9 \\
\hline & $\begin{array}{l}\text { Both wash and } \\
\text { peel }\end{array}$ & 2 & 4.5 \\
\hline & $\begin{array}{l}\text { Without wash or } \\
\text { peel }\end{array}$ & 20 & 45.5 \\
\hline
\end{tabular}

Assessment of $\mathrm{XO}$ activity is based on the principle of producing uric acid from xanthine in $\mathrm{XO}$ environment by accepting the presence of $\mathrm{XO}$ in the sample (13-15).

NO assessement was performed by the Moshage et al. (15) method. Measurements were done in 545 $\mathrm{nm}$ and the results were evaluated as $\mu \mathrm{mol} / \mathrm{L}(16,17)$.

ARE measurement have been realized by the help of ARE kits spectrophotometrically which were developed by Aslan et al. (18).

Questionnaire: In order to learn nutrition qualities of agriculture workers, nutrition questionnaires were applied (Table 2). The questionnaires were prepared by the study group. The data in this research was collected by questionnaire form which was prepared by possibility nutritional habits about changing some parameters in blood related with pesticides. Especially habits of washing fruits and vegetables and consuming of food while working were asked to workers. The data in this research was collected by questionnaire form which was prepared by surveying all the related literature by the researcher. Data were evaluated using correlation, crosstab, percentage and frequency distributions on the computer program SPSS statistical package program (17.0)

\begin{tabular}{|c|c|c|c|}
\hline & $\begin{array}{l}\text { Study group } \\
(n=44)\end{array}$ & $\begin{array}{l}\text { Control group } \\
(n=30)\end{array}$ & $\mathbf{p}$ \\
\hline XO (U/mL) & $2.01 \pm 0.26$ & $0.83 \pm 0.36$ & 0.0372 \\
\hline $\mathrm{NO}(\mu \mathrm{mol} / \mathrm{L})$ & $8.25 \pm 1.69$ & $5.87 \pm 2.13$ & 0.0458 \\
\hline ARE (U/L) & $7.25 \pm 1.22$ & $10.25 \pm 1.63$ & 0.0354 \\
\hline
\end{tabular}

\section{Statistical Analysis}

All statistical analyses were performed using commercially available software (SPSS version 17.0; SPSS, Inc, Chicago, Illinois). The datas were evaluated by the Kolmogorov-Smirnov test because they did not show a normal distribution. In evaluation of nutrition questionnaires frequencies were used. The data are provided as median (min-max). To compare continuous variables, the Student t-test was used. Statistical significance was set at $p<0.05$.

\section{Results}

Socio-demographic characteristics of each group were shown in Table 1 . The results of greenhouse workers' nutritional habits were shown in Table 2. The levels of XO, ARE and NO in blood samples of each groups were shown in Table 3. The statistics showed 
that levels of XO and $N O$ in pesticides-exposed workers were significantly higher compared to nonexposed group and the level of ARE was significantly lower in pesticides-exposed workers when compared with non-exposed group, respectively $(p<0.05)$.

The results of study showed that workers eat fruits without washing (45.5\%). Another important result in this research is that workers are feeding during application of pesticides (45.5\%). Workers skip breakfast compared to other meals (27.2\%).

\section{Discussion}

Recently, Isparta has become one of the most important provinces known for its productions of greenhouse vegetable cultivation and greenhouse carnation besides over production of apples and cherries (19). Therefore, greenhouse workers have adverse effects as a result of spraying pesticides in these regions. The most harmful toxicological impacts of these pesticides are over balance of oxidantantioxidant, and several studies also support this (49,20-22). Greenhouse workers and other workers in this area are more susceptible to harmful effects of pesticides as a result of spraying. Because pesticides are not diffused during spraying and after spraying they fold over there a long time. So, greenhouse workers are exposed to harmful effects of pesticides.

In this study, the blood of greenhouse workers was taken just after spraying. According to the results, increase of $\mathrm{XO}$ and NO levels, and significantly decrease of ARE level which is one of the antioxidant defense system enzymes are detected, respectively.

To examine role of oxidative/nitrosative stress in human, measurement of cellular lipid peroxidation, total antioxidant capacity, concentration of total thiol group, and determination of total NO in blood are recommended $(23,24)$.

El-Gohary et al. (23) have been examined kind of pyrethroid on rats NO production and its effect. And as a result, effects of pesticides on NO production have been determined.

Ayub et al. (24) determined that malathion which is OPs has effected NO production on rats. At present study activity of NO has been found about $8.25 \pm 1.69$ in workers and control groups $5.87 \pm 2.13$. Activity of NO shows a significant increase in workers group than control group $(p<0.05)$.

Terzi et al. (25) have examined rotenone's effects which is plant origin pesticide on NO levels of Wistar albino rats. They have given rotenone three different dose to three different group and they haven't given any rotenone to last group. The results of study showed that there have been no differences between control group and other group in XO activity (25).

$X O$ catalyzes the conversion of hypoxanthine to xanthine and that of xanthine to uric acid, which are the last steps in purine catabolism; product of these processes is a toxic superoxide radical. This reaction is, therefore, considered to be an important potential source of oxygen free radicals in vivo $(26,27)$.

At present study while $X O$ activity was identified average in worker group as $2.01 \pm 0.26$, in control group this rate was identified average as $0.83 \pm 0.36$. XO activity increased considerably in worker group as compared to control group. Investigations applied in this study region showed that the most intense usage of Ops came true in this region and each in turn synthetic pyrethroid group and insecticides and carbamate group insecticides followed it. Besides these results, it was identified in this research that workers were not protected or they take a bit measures during application of drug. A great deal of study applied in this region and country support it (28-30). So agrarian drug enforcers and producers considered not enough warning of authorities. Therefore environment and health problems occur of course $(31,32)$.

Human serum ARE [(ARE, EC 3.1.1.2, also known as paraoxonase1 (PON1)] originates from liver with two subtypes. PON1 activity in serum was associated with plasma lipid peroxidation and cardiovascular diseases (33). PON-1 and ARE (ARY) are considered two separate enzymes in spite of their marked biological similarities. Plasma PON-1 catalyzes the hydrolysis of the bioactive organophosphate metabolite paraoxon to nontoxic products as p-nitrophenol and diethyl-phosphoric acid. At the same time, ARE is another aromatic esterase that inactivates the same organophosphate pesticide but unlike PON1 is not inhibited by cholinesterase inhibitors as phesostigmine (eserine) (34). In this research, ARE levels were determined low levels of workers. The decline in blood levels may be due to chronic pesticide exposure. Workers eat fruits without washing (if fruits are washed, pesticides remove largely).

In this paper while evaluating $\mathrm{XO}, \mathrm{NO}$ and $\mathrm{ARE}$ level of pesticides exposure works at the same time some questions about nutritional habitual were 
asked. Because not only application of pesticides but also wrong habits while working can cause exposure of pesticides. And according to the results of questionnaire, greenhouse workers made some mistakes about their nutrition. Especially, consuming food/fruits during application of pesticides is the worst mistake. Since workers eat any food, pesticides can get into the body (via the digestive tract). And eating vegetables or fruits without washing is another significant mistake.

As given in Table 2, workers are fed three meals a day largely (68.1\%). This is a condition required and recommended. Workers generally do not skip meals. They do not have breakfast because workers start to work early in the morning. Workers skip the dinner meal minimal. The reason for this, all family members want to get together at dinner time. Another remarkable point in Table 3 is that workers feed during application of pesticides. This is an extremely dangerous situation because workers may be exposed to pesticides through skin and respiratory tract.

One point that is salient in nutrition surveys is that half of agricultural workers eat foods without cleaning and peeling, when they eat fruit. Also, agricultural workers eat tomatoes in greenhouse during their production without cleaning. Up taking of pesticide through digestive system by agricultural workers may derive from tomatoes that are eaten during and afterwards pest control, therefore parameters in this research may be impressed from it. Research carried out in this region show us that agricultural workers eat fruits during pest control and don't take measures efficiently $(35,36)$. Also agricultural workers eat, drink during pest control, therefore quantity of pesticide uptake may go up; it may give rise to several health problems. Also levels of $\mathrm{XO}, \mathrm{NO}$ and ARE may be impressed negatively.

\section{Conclusion}

All in all pesticide usage is urgent in modern agriculture. But while using pesticide against diseases in crops, human health should be considered also. And negative impressions of agricultural pesticides on humans are very big social issue. This research is aimed to determine whether the pesticides are indeed negative impressions of oxidant- antioxidant balance of agricultural workers. And this oxidant- antioxidant imbalance can be increased hazard of atherosclerosis, abiotrophy and cancer in agricultural workers. Avoiding and reducing exposures to pesticides will reduce the harmful effects from pesticides. Some taking sample measurement can be provided protection. In order to avoid exposures, safety systems can be used- such as closed systems and enclosed cabs, and wearing appropriate personal protective equipment. And also washing exposed areas often may be another solution for this problem. Researchers must be sensitive above this issue and to try to find new solutions. As we can see from workers nutritional habits, they don't wash their fruits and vegetables and they drink water while working. If they don't do these habitual actions while working they may reduce harmful effect of pesticides, too. We believe that these problems can be reduced with the application of necessary precautions and pest control with stated doses.

\section{Acknowledgments}

We thank Süleyman Demirel University Research funding (SDU-BAP; project number: 1902-D-09) for financial support.

\section{Ethics}

Ethics Committee Approval: The study was approved by the Research Ethics Committee of Süleyman Demirel University (date: 20.02.2008, no: 01-17).

Informed Consent: All participants gave their verbal and written consents.

\section{Authorship Contributions}

Surgical and Medical Practices: S.Ö., E.Ö., F.G., E.K., Concept: S.Ö., E.Ö., F.G., E.K., Design: S.Ö., E.Ö., F.G., E.K., Data Collection or Processing: S.Ö., E.Ö., F.G., E.K., Analysis or Interpretation: S.Ö., E.Ö., F.G., E.K., Literature Search: S.Ö., E.Ö., F.G., E.K., Writing: S.Ö., E.Ö., F.G., E.K.

Conflict of Interest: No conflict of interest was declared by the authors.

Financial Disclosure: We thank Süleyman Demirel University Research funding (SDU-BAP; project number: 1902-D-09) for financial support.

\section{References}

1. Sataloğlu N, Aydın B, Turla A. Pestisit zehirlenmeleri. TSK Koruyucu Hekimlik Bülteni 2007; 6: 169-74.

2. McEwen FL, Stephenson GR. The use and significance of pesticides in the environment, New York: John Wiley \& Sons Pub, 1979; 538. 
3. Kılınç K. Oksijen radikalleri: üretilmeleri, fonksiyonları ve toksik etkileri. Biyokimya Derg 1985; 10: 60-89.

4. Banerjee BD, Seth V, Bhattacharya A, Pasha ST, Chakraborty AK. Biochemical effects of some pesticides on lipid peroxidation and free-radical scavengers. Toxicol Lett 1999; 107: 33-47.

5. Shadnia S, Azizi E, Hosseini R, Khoei S, Fouladdel S, Pajoumand $A$, et al. Evaluation of oxidative stress and genotoxicity in organophosphorus insecticide formulators. Hum Exp Toxicol 2005; 24: 439-45.

6. Ranjbar P, Pasalar P, Abdollahi M. Induction of oxidative stress and acetylcholinesterase inhibition in organophosphorous pesticide manufacturing workers. Hum Exp Toxicol 2002; 21: 179-82.

7. Hernández AF, López $O$, Rodrigo L, Gil F, Pena G, Serrano JL, et al. Changes in erythrocyte enzymes in humans long-term exposed to pesticides: influence of several markers of individual susceptibility. Toxicol Lett 2005; 159: 13-21.

8. Valko M, Izakovic M, Mazur M, Rhodes CJ, Telser J. Role of oxygen radicals in DNA damage and cancer incidence. Mol Cell Biochem 2004; 266: 37-56.

9. Cuzzocrea S, Riley DP, Caputi AP, Salvemini D. Antioxidant therapy: a new pharmacological approach in shock, inflammation, and ischemia/reperfusion injury. Pharmacol Rev 2001; 53: 135-59.

10. Özdin M, Gürsu M.F. Koroner kalp hastaları ile çeşitli risk faktörlerini taşıyan bireylerde paraoksonaz 1 ve arilesteraz aktiviteleri ile fenotiplerinin araştırılması. Uzmanlık Tezi. Fırat Üniversitesi Tıp Fakültesi Biyokimya ve Klinik Biyokimya Anabilim Dalı, Elazığ. 2003.

11. Li WF, Costa LG, Furlong CE. Serum paraoxonase status: a major factor in determining resistance to organophosphates. J Toxicol Environ Health 1993; 40: 337-46.

12. Gürsu M.F, Özdin M. Sigara içenlerde serum paraoksonaz (PON1) aktiviteleri ile malondialdehit düzeylerinin araştırılması. Fırat Tıp Dergisi 2002; 7: 732-7.

13. Prajda N, Weber $\mathrm{G}$. Malignant transformation-linked imbalance: decreased xanthine oxidase activity in hepatomas. FEBS Lett 1975; 59: 245-9.

14. Rencüzoğulları N. Ratlarda deneysel olarak oluşturulan kadmiyum toksikasyonu üzerine likopenin etkilerinin araştırılması. Mustafa Kemal Üniversitesi, Sağılık Bilimleri Enstitüsü, Biyokimya (Vet) Anabilim Dalı, Yüksek Lisans Tezi, Hatay. 2006.

15. Moshage $H$, Kok B, Huizenga JR, Jansen PL. Nitrite and nitrate determinations in plasma: a critical evaluation. Clin Chem 1995; 41: 892-6.

16. Cavdaroglu B. Postmenopozal osteoporozlu hastalarda oksidatif stresin değerlendirilmesi ve proinflamatuar sitokinler ile biyokimyasal belirleyicilerin ilişkisinin araştrılması. Erciyes Üniversitesi, Tıpta Uzmanlık Tezi, 2007.

17. Moshage $H$, Kok $B$, Huizenga JR, Jansen PL. Nitrite and nitrate determinations in plasma: a critical evaluation. Clin Chem 1995; 41: 892-6.

18. Aslan M, Kosecik M, Horoz M, Selek S, Celik H, Erel O. Assessment of paraoxonase and arylesterase activities in patients with iron deficiency anemia. Atherosclerosis. 2007; 191: 397-402.

19. Anonymous. Tarım İ Müdürlügü Kayıtları, Isparta, 2008.
20. Tankut i. Pestisitlerin mikrobiyal parçalanması. Süleyman Demirel Üniversitesi, Mühendislik Mimarlık Fakültesi, Çevre Mühendisliği Bölümü bitirme ödevi. 1997.

21. Kara IH, Güloğlu C, Karabulut A, Orak M. Sociodemographic, clinical, and laboratory features of cases of organic phosphorus intoxication who attended the Emergency Department in the Southeast Anatolian Region of Turkey. Environ Res 2002; 88: 82-8.

22. Guloglu C, Aldemir M, Orak M, Kara IM. Dichlorvos Poisonıng After Intramuscular Injection. American Journal Of Emergency Medicine 2004; 22: 328-9.

23. El-Gohary M, Awara WM, Nassar S, Hawas S. Deltamethrininduced testicular apoptosis in rats: the protective effect of nitric oxide synthase inhibitor. Toxicology 1999; 132: 1-8.

24. Ayub S, Verma J, Das N. Effect of endosulfan and malathion on lipid peroxidation, nitrite and TNF-alpha release by rat peritoneal macrophages. Int Immunopharmacol 2003; 3: 1819-28.

25. Terzi A, Iraz M, Sahin S, Ilhan A, Idiz N, Fadillioglu E. Protective effects of erdosteine on rotenone-induced oxidant injury in liver tissue. Toxicol Ind Health 2004; 20: 141-7.

26. Aranda R, Doménech $E$, Rus AD, Real JT, Sastre J, Viña J, et al. Age-related increase in xanthine oxidase activity in human plasma and rat tissues. Free Radic Res 2007; 41: 1195-200.

27. Zhang JW, Lv GC, Zhao Y. The significance of the measurement of serum xanthine oxidase and oxidation markers in patients with acute organophosphorus pesticide poisoning. J Int Med Res 2010; 38: 458-65.

28. Öğüt $S$, Küçüköner E. Isparta'da kullanılan tarım ilaçlarına karşı üreticilerin tutum ve davranışları. Tarım Ilaçları Kongre ve Sergisi, Bildiriler Kitabı 2007: 378-85.

29. Anonymous. Türk Tarımında Kimyasal İlaç Kullanımı: Etkinsizlik, Sorunlar ve Alternatif Düzenlemelerin Etkileri. T.C. Tarım ve Köyişleri Bakanlığı, Ankara: Tarımsal Ekonomi Araştırma Enstitüsü Yayınları 2001; 63.

30. Tanrıvermiş H. Orta Sakarya Havzası'nda domates üretiminde tarımsal ilaç kullanımının ekonomik analizi. Ankara: T.C. Tarım ve Köyişleri Bakanlığı, Tarımsal Ekonomi Araştırma Enstitüsü Yayınları 2000; 42.

31. Demircan V, Yılmaz $\mathrm{H}$. Isparta ili elma üretiminde tarımsal ilaç kullanımının çevresel duyarlıık ve ekonomik açıdan analizi. Ekoloji 2005; 14: 15-25.

32. Yang ZP, Dettbarn WD. Lipid peroxidation and changes in cytochrome $c$ oxidase and xanthine oxidase activity in organophosphorus anticholinesterase induced myopathy. J Physiol Paris 1998; 92: 157-61.

33. Berkowitz GS, Wetmur JG, Birman-Deych E, Obel J, Lapinski $\mathrm{RH}$, Godbold JH, et al. In utero pesticide exposure, maternal paraoxonase activity, and head circumference. Environ Health Perspect 2004; 112: 388-91.

34. Eckerson HW, Wyte CM, La Du BN. The human serum paraoxonase/arylesterase polymorphism. Am J Hum Genet 1983; 35: 1126-38.

35. Ogut S, Gultekin F, Kisioglu AN, Kucukoner E. Oxidative stress in the blood of farm workers following intensive pesticide exposure. Toxicol Ind Health 2011; 27: 820-5.

36. Ögüt $S$, Küçüköner $E$, Gültekin $F$. The effects of pesticides on greenhouse workers and their produced products. Toxicol \& Environ Chem 2012; 94: 403-10. 